\title{
Peculiar features of application of a method «Penman - Monteith» in conditions of drip irrigation of Steppe of Ukraine (on an instance of grain corn)
}

M. Romashchenko, Academician of the NAAS,

Doctor of Technical Sciences

A. Shatkovskiy, O. Zhuravliov, Candidates of Agricultural Sciences

Institute of Water Problems and Reclamation NAAS

The purpose. To study features and to adapt rated method of determination of total evaporation «Penman Monteith» for conditions of drip irrigation of Steppe of Ukraine. Methods. Field short-term experiments, conventional analytical research techniques; dispersion, correlation, regression and variation analysis. Results. With the use of modern tooling (Internet-meteorological station iMetos $\AA$, station of soil moisture iMetos $®$ $\mathrm{SM} / \mathrm{ECHO} / \mathrm{TNS} / \mathrm{ECOD} 2)$ they determined specific benchmark ETo, rated and actual values of total evaporation ETc. On the basis of results of field experiment they adjusted quotient of crop Kc according to phases of growth of plants of corn with the use of deflexions from reference conditions. Conclusions. It is fixed that value of actual quotient of crop Kc for grain corn in conditions of drip irrigation of Steppe of Ukraine differs from standard $\mathrm{Kc}(\mathrm{FAO})$. Considering precise correlation between $\mathrm{Kc}$ (FAO) and $\mathrm{Kc}$ (cor.) for determination of actual evapotranspiration (ETc) of plants of corn they recommend to use corrected values of Kc.

Key words: evapotranspiration, quotient of crop, irrigation requirement, drip irrigation, corn for grain.

\section{Problem statement and literature review}

The biological basis of irrigation's mode is a total water consumption of plants or evapotranspiration (ETc). Under the ETS we understand the total volume of water that evaporates during the vegetative period by plants and soil surface (physical evaporation $-\mathrm{K}_{\mathrm{e}}$ ) infiltrate into the lower soil's horizons and spends by plants on transpiration $\left(K_{c b}\right)$.

Determining factors that influence the value of the ETc are the climate of zone and weather conditions of current or calculated growing season of their cultivation.

Determination of agricultural crops' water consumption is a key issue from the solution of which depends the values of irrigation's rates, efficiency and ecological consequences of irrigation.

In the practice of irrigated agriculture water consumption is calculated using different methods: by the data of special experiments, by the coefficients of transpiration and water consumption, on the base of water balance's equations and so on.

At present there are many methods by which evapotranspiration has determined on the basis of meteorological parameters and biological characteristics of agricultural crops. At the irrigated conditions of the Steppe zone of Ukraine at different times practically applicated the following methods: bioclimatic method of A.M. Alpatyeva (1954) [1], and later it was improved by S.M. Alpatyev (1965) [2] and V.P. Ostapchykom (1989) [3], biophysical method of D.A. Shtoyko (1971), [4] M.M. Ivanova (1954) [5] and others.

In the world for a long time been widespread methods of Penman (1956) [6] and Blaney-Criddle (1950) [7]. Taking into account a certain inexactness of these methods in the 1990 council of experts in FAO had recommended approving of the combined method of «Penman-Monteith» as the standard for calculation of an etalon total evapotranspiration (ETo).

The method predicts determination of ETo of a hypothetical culture with a height of $0,12 \mathrm{~m}$, the surface resistance of $70 \mathrm{~cm}^{-1}$ and albedo of 0,23 , similar to the a lawn grass with the same height in a phase of active vegetation and sufficiently moistured. Design equation of Penman-Monteith was determined from the equation of energy balance of soil surface, and the dependence of ETc to ETo displays a coefficient of a culture Kc, which describes the differences between a typical crop and standard lawn grass [8, 9, 10]. 
The values of $\mathrm{Kc}$ are typical values, expected for average $\mathrm{Kc}$ in standard climatic conditions that are defined as sub-humid climate (kind of steppe climate, most provided with precipitations) with the average daily minimal air humidity $\mathrm{RHmin} \approx 45 \%$ and an average wind speed of $2 \mathrm{~m} / \mathrm{sec}$. Arid climate and higher wind speed causing an increase of Kc's values $[8,11,12]$. The climatic conditions of Dry Steppe of Ukraine (RHmin $\approx 30 \%$, $v \approx 3 \mathrm{~m} / \mathrm{s}$ ) differs from the typical FAO, so for the practical application of the «Penman- Monteith» method, is necessary to adjustment Kc, taking into the account deviations from standard conditions [13].

The methodology and methods of researches

Field experiments were conducted on lands of SE "HH" Brylivske' Institute of Water Problems and Land Reclamation NAAS (Dry Steppe subzone - the climate is lukewarm, very dry) $-46^{\circ} 40^{\prime}$ of north latitude, $33^{\circ} 12^{\prime}$ of east longitude, altitude - 17 meters. Soil - dark brown residual alkaline light-loamy.

Experiments were conducted in the 2013-2015yy on a culture of a grain corn (hybrid DKC 5276 DEKALB®, FAO 460 by «Monsanto»). For the recording of meteorological parameters used online weather station iMetos $®$, which was located directly on the experimental plot. ETo determined using CropWat 8.0. The actual evapotranspiration ETc determined using the internet station of soil moisture monitoring iMetos ${ }^{\circledR S M} / E C H O / T N S / E C O D 2$, which was equipped with soil moisture sensors Watermark 200SS type on different depths of soil profile and distances from the point of water supply. 
As Kc actually depends on the phase of culture's development, corn growing season was divided into three parts: an initial, middle and final phase.

\section{Results.}

Determined that in a 2013 actual average daily evaporation ETc differs from evapotranspiration ETc(FAO) calculated with a using of the cultures coefficient $\mathrm{Kc}(\mathrm{FAO})$ (Fig. 1). Thus, during the period "emergence of seedlings

- headling of panicles" (I decade of May - III of June) and from the milk ripeness before harvesting (II decade of July - I of September) ETc(FAO) exceeds the actual average daily evaporation respectively on 20 and $28 \mathrm{~m}^{3} /$ ha.

From the headling of panicles to milky ripeness (III decade of June - II of July) $\operatorname{ETc}(F A O)$ is less than the actual evaporation at average on $10 \mathrm{~m}^{3}$ /ha. At time of corn's emergence seedling $\mathrm{Kc}$ (FAO) was 0,65 , that in conditions of 2013 was at 4.7 times higher than actual Kc.

Within a May and I-II decades of June $\mathrm{Kc}(\mathrm{FAO})$ correspondently was in 3/1 and 1,2 times higher than actual value of $\mathrm{Kc}$. From venting of panicles to milky ripeness (crucial period as for water consumption) $\mathrm{Kc}(\mathrm{FAO})$ was on

$10 \%$ lower than the actual Kc. During maturation (from milk to full ripeness) $\mathrm{Kc}(\mathrm{FAO})$ once again exceeds the actual value at 1,5 times and at the first week of September - in 11 times.

During corn's growing season (May-September) in 2013 precipitations were equal to $138 \mathrm{~mm}$ (middle dry). By the appointment of irrigations by instrumental method were conducted 30 vegetation waterings with an irrigation rate $4500 \mathrm{~m}^{3} / \mathrm{ha}$, total water consumption was equal to $5949 \mathrm{~m}^{3} /$ ha. Lower ETc (actual) in 2013 (in comparison with 2014-2015) was associated with low temperature mode and rainy weather in July, when ETo = $5,79 \mathrm{~mm} /$ day (in the 2014-2015 - 7,37-7,35 mm/day).

Appointment of irrigations by the method of Penman-Monteith required holding of 5 additional vegetation waterings, which, increased irrigation rate and total water consumption at 750 and $712 \mathrm{~m}^{3} / \mathrm{ha}$ correspondently. The productivity of dry grains ( $14 \%$ humidity) by the different methods of irrigation appointment was within 16,8-17,1 tons/ha (by LSD05 $=0,7 \mathrm{t} / \mathrm{ha}$ ).

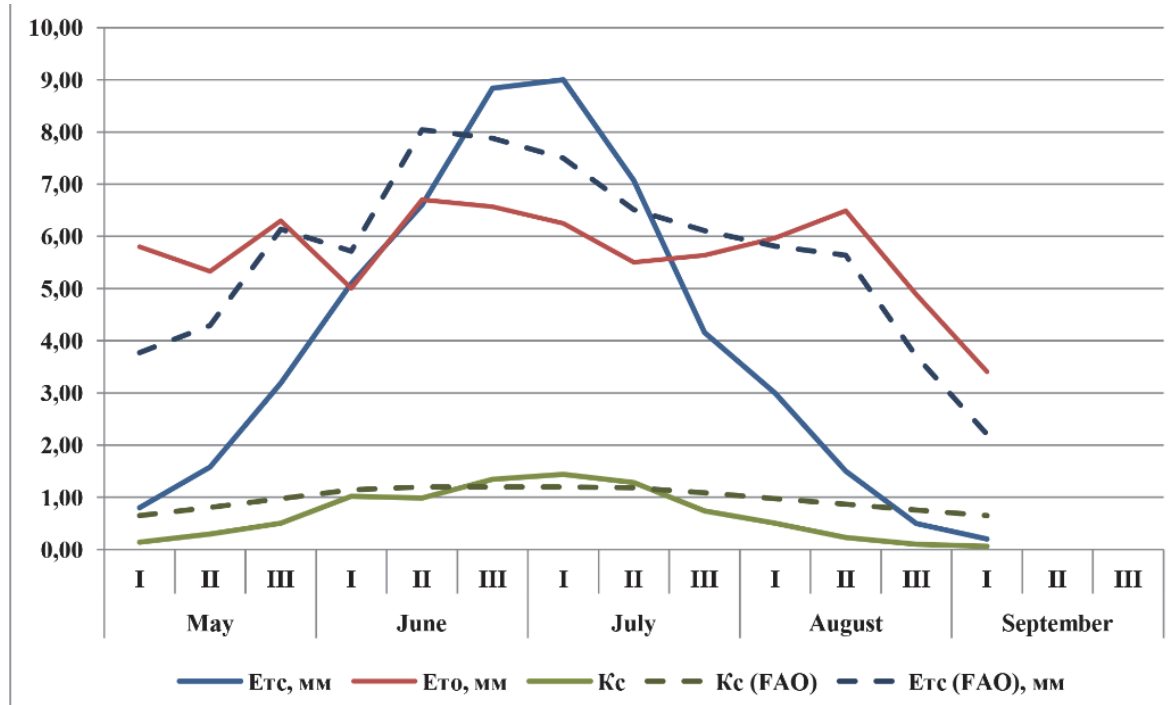

Figure 1 - Evapotranspiration and Kc of corn - 2013 year.

By the method of Penman-Monteith in 2014 from germination to the $\left.\right|^{\text {st }}$ decade of June and from $I^{\text {st }}$ decade of August to harvesting the total average daily evaporation exceeded actual accordingly on 20 and $30 \mathrm{~m}^{3} / \mathrm{ha}$ (Fig. 2). At the same time from the second decade of June to the third decade of July, on the contrary - the average daily evaporation reduced on $20 \mathrm{~m}^{3} / \mathrm{ha}$. $\mathrm{Kc}(\mathrm{FAO})$ at the initial and final phases of the culture's development exceeded actual respectively at the 65 and $85 \%$, and in the middle of the season, on the contrary - was lower on $20 \%$. Over the vegetation period of 2014 dropped out 145,6 mm of precipitations (middle dry year). By the appointment of irrigation by instrumental method were conducted 38 vegetation irrigations with an 
irrigation rate $5700 \mathrm{~m}^{3} / \mathrm{ha}$, total water consumption was equal to $7369 \mathrm{~m}^{3} / \mathrm{ha}$. Appointment of waterings by the method of Penman-Monteith required 4 additional vegetation waterings, which, respectively, has increased the irrigation rate and total water consumption on 600 and $544 \mathrm{~m}^{3} / \mathrm{ha}$. Grain's yield by the different methods of irrigation's terms appointment was within 17,1-17,5 tons/ha ( $\operatorname{LSD}_{05}=0,6 \mathrm{t} / \mathrm{ha}$ ).

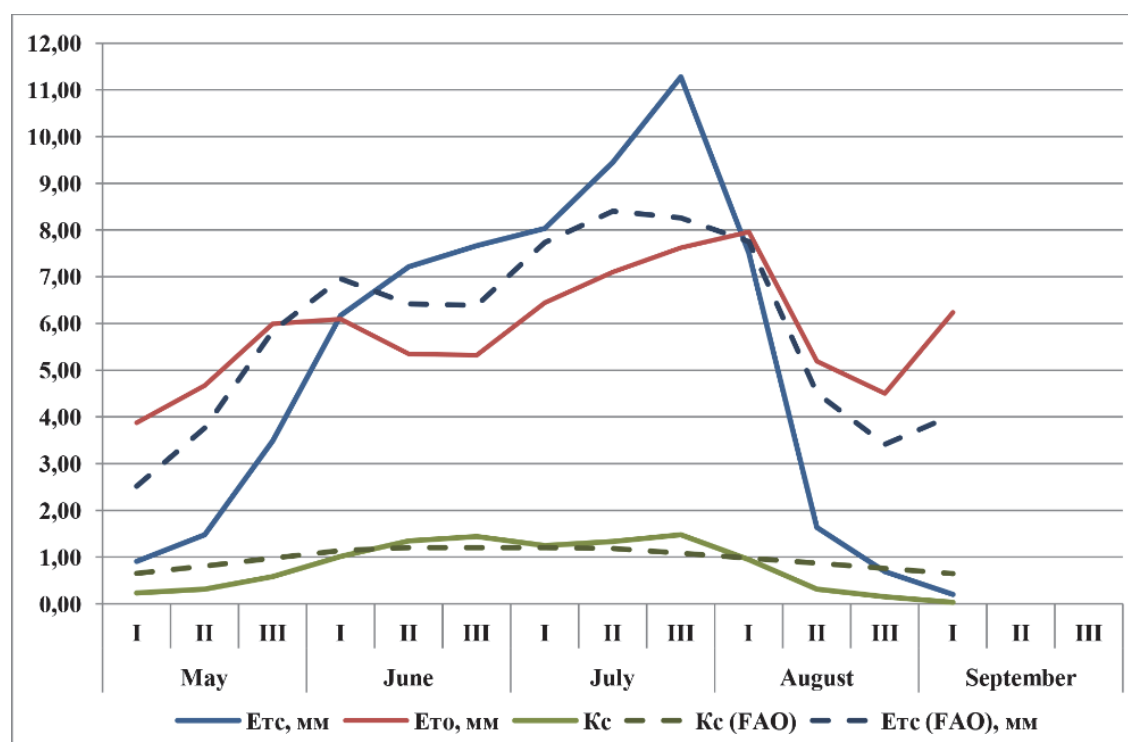

Figure 2 -n Evapotranspiration and Kc of corn - 2014 year.

According to Penman-Monteith's method at 2015 from germination till I decade of June and from the II decade of August to harvesting the total average daily evaporation had exceeded the actual on $20 \mathrm{~m}^{3} / \mathrm{ha}$. While, as from the II decade of June till I decade of July, on the contrary, - the average daily evaporation had reduced on $10 \mathrm{~m}^{3} / \mathrm{ha}$. $\mathrm{Kc}(\mathrm{FAO})$ at the initial and final phases of the culture's development exceeded the actual on 75 and $80 \%$ accordingly, and in the middle of the season, on the contrary - was lower on $10 \%$.

Over the vegetation period in 2015 dropped out $335,2 \mathrm{~mm}$ of precipitations (medium humid). According to appointment of irrigations by the instrumental method were conducted 25 waterings with an irrigation rate of $3750 \mathrm{m3} / \mathrm{ha}$, total water consumption was equal to $7841 \mathrm{~m}^{3} / \mathrm{ha}$. Appointment of waterings by the method of Penman-Monteith required 7additional waterings, which, respectively, increased the irrigation rate and total water consumption on 1050 and $1035 \mathrm{~m}^{3} / \mathrm{ha}$. The yield of dry grains (14\%) by the

different methods irrigation's terms appointment was within $16,8-17,0$ tons/ha (by $\operatorname{LSD}_{05}=0,8 \mathrm{t} / \mathrm{ha}$ ).

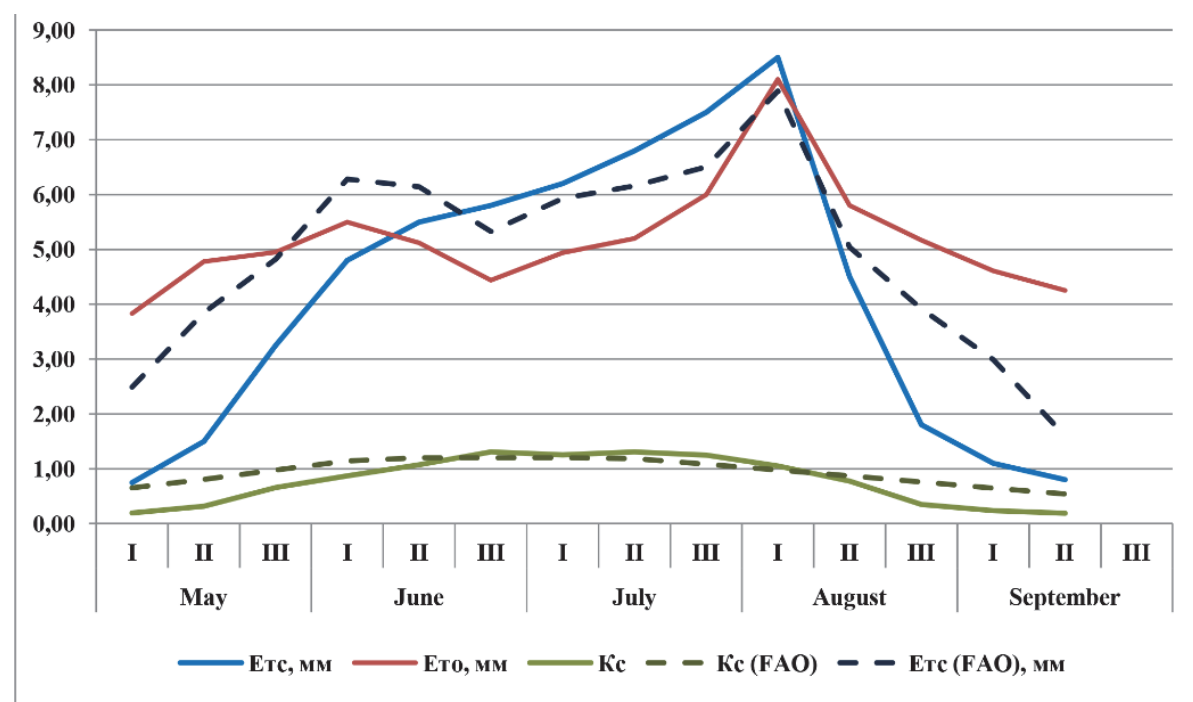

Figure 3 - Evapotranspiration and Kc of corn - 2015 year

Thus, for a three years of investigations $\mathrm{Kc}$-actual although it was slightly different, but its relationship to the $\mathrm{Kc}(\mathrm{FAO})$ is clearly correlated in time, that gives us possibility for further calculations of the average daily evaporation by the method of Penman-Monteith, adopt the average value of Kc-accepted (Kc(ac.) (Fig. 4). Can state that the value of $\mathrm{Ks}(\mathrm{ac}$.) for the culture of corn in the conditions of Steppe differs from typical $\mathrm{Kc}(\mathrm{FAO})$. Thus, at the initial stage of development of corn $\mathrm{Kc}(\mathrm{FAO})$ was higher than Ks-act. from 225 to $20 \%$, 
what, as calculations show, is a consequence of excessive irrigation during this period approximately 1000 $\mathrm{m}^{3} /$ ha. Within the season (II decade of June - III decade of July), when observed the critical period as for corn's water consumption, $\mathrm{Kc}(\mathrm{FAO})$ on the contrary - at $10-15 \%$ lower than the $\mathrm{Kc}(\mathrm{ac}$.) which, in turn, already causes moisture deficit within $400-500 \mathrm{~m}^{3} / \mathrm{ha}$. From the beginning of the final phase up to harvesting of grain, $\mathrm{Kc}(\mathrm{FAO})$ again exceeds $\mathrm{Kc}\left(\mathrm{ac}\right.$.) at $20-215 \%$, causing over watering at $500-600 \mathrm{~m}^{3} / \mathrm{ha}$.

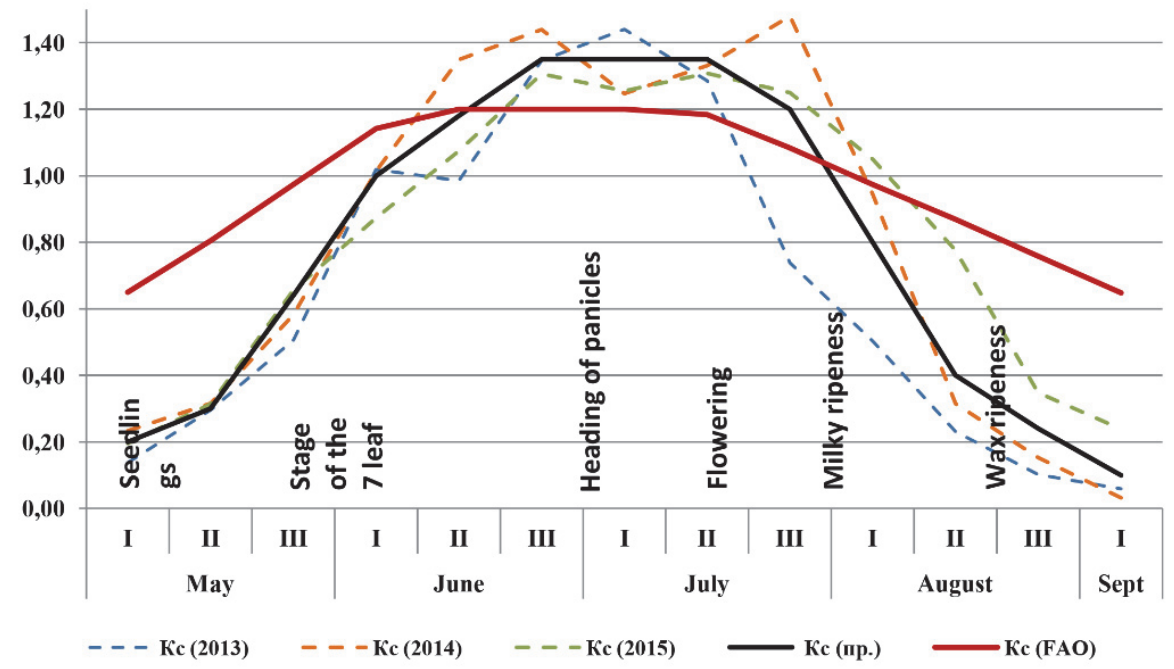

Figure 4 - Dynamics of changes during the growing season of corn and the ratio of $\mathrm{Kc}(\mathrm{FAO})$ and $\mathrm{Kc}(\mathrm{ac})$.

For determination of ETc of corn for grain should have ETO calculated by the method of PenmanMonteith (in the program "ETO Calculator» [14] or other) for a certain period of time (day or decade) multiplied on the corresponding average decade value of the crops coefficient (table. 1).

Table 1 - Average decade values of corn's coefficient Kc

\begin{tabular}{|c|c|c|c|c|c|c|c|c|c|c|c|c|}
\hline \multicolumn{4}{|c|}{ May } & \multicolumn{4}{c|}{ June } & \multicolumn{4}{c|}{ July } & \multicolumn{4}{|c|}{ August } & September \\
\hline I & II & III & I & II & III & I & II & III & I & II & III & I \\
\hline 0,20 & 0,30 & 0,64 & 1,0 & 1,18 & 1,35 & 1,35 & 1,35 & 1,2 & 0,8 & 0,4 & 0,24 & 0,10 \\
\hline
\end{tabular}

Using software CropWat [11], iMetos (application «Irrimet») is convenient to use the data of table 2 :

Table 2 Coefficient $\mathrm{Kc}$ for corn by conventional phases of development Conventional phase of plants

\begin{tabular}{|l|l|l|}
\hline Conventional phase of plants development & Data & Kc \\
\hline Initial & 05 of May & 0,20 \\
\hline Early middle & 25 of June & 1,35 \\
\hline Termination of the middle & 25 of July & 1,35 \\
\hline Almost final phase & 05 of September & 0,10 \\
\hline
\end{tabular}

\section{Conclusions}

1. By results of researches established that the value of the actual cultures coefficient $\mathrm{Kc}$ for for grain corn in the conditions of Steppe of Ukraine differs from the typical $\mathrm{Kc}(\mathrm{FAO})$.

2. At the initial and final stages of development of corn $\mathrm{Kc}(\mathrm{FAO})$ is higher than the the actual value on 20 to $225 \%$, and in the middle of the season, on the contrary - is lower on $10-15 \%$. This leads to an excessive irrigation at the beginning and end of the growing season of corn and to the moisture's content deficit at the critical period of plants development.

3. Considering the clear correlation of $\mathrm{Kc}(\mathrm{FAO})$ and $\mathrm{Kc}(\mathrm{ac}$.) for determination of the actual evapotranspiration (ETC) of grain corn plants in the conditions of a drip irrigation in the Steppe of Ukraine recommended using of the corrected values of Kc (see. Table 1-2). 


\section{Bibliography}

1. Alat'ev A.M. Vlahooborotb $v$ pryrode y ykh preobrazovanyya/A.M. Alpat'ev. - Lenynhrad: Hydrometeoyzdat, 1969. - $322 \mathrm{~s}$.

2. Alpat'ev S.M. O polyvnыkh rezhymakh sel'skokhozyaystvennыkh kul'tur/S.M. Alpat'ev//Oroshaemoe zemledelye v evropeyskoy chasty SSSR: v kn. - M., 1965. - S. 185-190.

3. Ynformatsyonno-sovetuyushchaya systema upravlenyya oroshenyem/pod redaktsyey V.P. Ostapchyka I. - K.: Urozhay, 1989. - $248 \mathrm{~s}$.

4. Shtoyko D.A. Rozrakhunkovi metody vyznachennya sumarnoho vyparovuvannya i strokiv polyvu sil's'kohospodars'kykh kul'tur/D.A. Shtoyko, V.A. Pysarenko, O.S. Bychko, L.I. Yelazhenko//Zb. Zroshuvane zemlerobstvo. - K.: Urozhay, 1977. - Vyp. 22. - S. 3-11.

5. Yvanov N.N. Ob opredelynyy velychyn ysparyaemosty/N.N. Yvanov//Yzvestyya VHO. - 1954. - № 2, T 86. - 189-196.

6. Penman H.L. Evaporation. An Introductory Survey/H.L. Penman//Neth. J. Agr. Sci., 1956/- Vol. 4 - P. 929.

7. Blaney H.F. Determining Water Requirements in Irrigated Areas from Climatologically and Irrigation Data/H.F. Blaney, W.D. Criddle//US Soil Cons. Serv. SCS-TR-96, 1950. - 48 p.

8. Allen R.G., Pereira L.S., Raes D., Smith M. Crop evapotranspiration - Guidelines for computing crop water requirements//FAO Irrigation and drainage paper 56//Food and Agriculture Organization of the United Nations. - Rome, 1998.

9. Blaine Hanson. Crop Coefficients. - Davis, University of California, 2008. - 54 p.

10. Richard G. Allen. Penman-Monteith Evapotranspiration Calculations: Reference ET and Crop Coefficients. - Colorado Evapotranspiration Workshop March 12. - 2010. - 124 r.

11. David M. Sumnera, Jennifer M. Jacobsb. Utility of Penman-Monteith, Priestley-Taylor, reference evapotranspiration, and pan evaporation methods to estimate pasture evapotranspiration//Journal of Hydrology. - 2005. - № 308. - P. 81-104.

12. E. Farg, S.M. Arafat, M.S. Abd El-Wahed, A.M. El-Gindy Estimation of Evapotranspiration ETc and Crop Coefficient $\mathrm{Kc}$ of Wheat, in south Nile Delta of Egypt Using integrated FAO-56 approach and remote sensing data.//The Egyptian Journal of Remote Sensing and Space Sciences. - 2012. - № 15. - P. 83-89.

13. Kokovikhin S.V. Perspektyvy vykorystannya metodu Penmana-Monteyta dlya vstanovlennya evapotranspiratsiyi v umovakh zroshennya Pivdnya Ukrayiny/S.V. Kokovikhin//Zroshuvane zemlerobstvo. 2010. Vyp. 54. - S. 280-286.

14. Step by Step Calculation of the Penman-Monteith Evapotranspiration (FAO-56 Method). [Elektronnyy resurs]. - Rezhym dostupu: http://edis.ifas.edu/ae459. Zaholovok z tytul. ekranu, 2016.

15.Kokovikhin S.V. Prohnozuvannya vodopotreby sil's'kohospodars'kykh kul'tur ta formuvannya hrafikiv polyviv z vykorystannyam prohramy «CROPWAT»/S.V. Kokovikhin//Zroshuvane zemlerobstvo. - 2011. Vyp. 55. - S. 298-303. 